UDC 316.323: 130.2

DOI: $10.21847 / 1728-9343.2018 .3(155) .139403$

MALTSEVA OLGA,

Candidate of Sciences in Philosophy,

Pryazovskyi State Technical University, Mariupol

\title{
SIMULATION OF LAUGHTER: THE EXPERIENCE OF RECONSTRUCTION
}

\author{
The paper looks into a phenomenon of postmodern simulation (simulacrization) of laughter. A \\ historical reconstruction of the simulation process of laughter is made on the basis of a universal \\ simulation algorithm proposed by J. Baudrillard, some intermediate counterpoints and kinds of \\ postmodern simulated laughter identified.
}

Key words: laughter; postmodern simulation of laughter; social functions of laughter.

Problem definition. Postmodern reality has been progressively turning into hyperreality. Technical facilities have been sweepingly evolving and meeting requirements of the hyperrealism epoch. As J. Baudrillard postulated, "(...) hyperrealism is the summit of art and the summit of reality owing to their interchange on the level of simulacrum (...)" [Бодріяр, 2004a: 8-12]. Most researchers of the postmodern sociocultural environment incline to the concept of simulacrum being the most engaged in postmodern scientific discourse. Today the term of simulacrum, introduced in philosophy by Plato as long ago as in classical times, still means the same: "ghost", "double", "similarity of a thing". However, it has been recently acquiring new shades of meaning, as the origin of simulacra and their functional impact on individual and society are interpreted in a different way. Contemporary postmodern society which is now habitually defined as a carnivalized environment highlights such an important social factor as laughter among numerous simulation objects.

Analysis of recent studies and publications. G. Bataille who revived the circulation of this concept in science in the latter half of the $20^{\text {th }}$ century interprets simulacra as sovereign moments, examples of the flight of existence and discontinuity of experience - those are the states of drunkenness, Eros, sleep, laughter etc. [Клоссовски, 1994]. The contemporary interpreters of such reading J. Baudrillard, A. Badiou, G. Deleuze, F. Jameson, A. Kojève and $P$. Klossowski introduced some additional connotations and expanded its content, greatly enriching the understanding of the essence of simulacra and the simulation process of the surrounding world, its transformation into hyperreality.

As an example, J. Baudrillard transfers the concept of simulacrum to the field of sociocultural experience. Furthermore, he argues that simulacra are certain markers of reality, which acquire their meaning only within a universal system produced by themselves, rather than merely a play of signs. Simulacra involve specific social relations while creating a peculiar chain: imitation - production - simulation. The author gives the following semantic meaning to the above concepts: "(...) imitation is a prevailing type of the classic epoch, from the Renaissance to the Industrial Revolution; production is a distinctive type of the industrial epoch; and simulation characterizes a modern development type of societies, which is regulated by codes" [Бодріяр, 2004a: 6-13]. Baudrillard singles out several stages of the simulacrization process: simple representation of reality - distortion of reality - masking of the absence of reality - false reality - simulacrum which bears no relation whatsoever to reality and is focused on itself.

Definition of a research area. There have been no indepth studies yet into a mechanism of laughter simulation i.e. transformation of a natural, uncontrolled reaction inherent in man into a simulated pattern. It should be taken into account here that all shades of laughter, from a smile to sarcasm, gradually turn into simulacra. A topical research task is therefore to reconstruct a historical process of laughter simulation.

The goal of the paper is to reconstruct the simulation process of laughter. To meet the goal set, the following tasks are fulfilled: prerequisites of postmodern simulation of laughter are examined; historical counterpoints of laughter simulation are identified; various kinds of postmodern simulated laughter are determined.

The research methodology includes a historical reconstruction method, system analysis, structural and functional analysis and J. Baudrillard's technique for reproduction of the simulation process.

Presentation of the basic material. Using as a methodological basis J. Baudrillard's philosophical conception covering a relationship between the simulation process and a sociocultural development pattern developed by the above philosopher, we may suggest a hypothesis that laughter underwent several stages in the course of the simulation process. These area precapitalist development stage (a ritually imitated burial form of laughter of traditional cultures); the late Middle Ages, the Renaissance (with ritual forms of carnival laughter intrinsic to it); a political economy stage (bourgeois-capitalist society with its endeavor to use imitations of laughter and smiles for rationally pragmatic and practical purposes, for example, a phenomenon of the American smile as opposed to the Duchenne smile, the use of laughter as a sign, symbol of success and pleasure in advertising and other kinds of mass culture); and a postmodern development stage of societies, which features prevalence of simulacra (a high level of production and information technologies, which allows to conveyorize simulacra and turn social realm into the world of entirely simulated - objectified, virtual, formalized etc. - laughter). Now let us look into details of the historical process of laughter simulation.

At the first stage of laughter simulation i.e. in traditional societies there were certain inherent human abilities used, namely an ability to imitate emotions including laughter. 
The human ability to laugh when it is not funny and there are no comic components inducing a laughing response gave rise to ritual laughter. The latter spread among the participants of an event owing to empathy. Usually ritual laughter was no burst of spontaneous, uncontrolled laughter; in fact, it manifested itself as imitation-counterfeit, playing an emotion, but eventually it developed into a sound laughing action which wave fully covered all actors involved in the ritual, bringing collective roar into an automatic state. As $\mathrm{H}$. Plessner indicated, laughter can plunge man into frenzy, he/she can rouse and evoke it in himself/herself at will. At the same time, "(...) by yielding to laughter and tears, we lose control of the body" [Plessner, 2003: 201-387]. Most ritual forms of laughter have this very mechanism for its appearance. As a rule, laughter begins as simulation and only later turns from mechanical to natural. Carnival laughter which has conserved archaic ritual forms of laughing behavior was by no means the sincere, merry and airy one at all times either. Here and there it was also demonstrative, feigned and pretended, its forced manifestations becoming a part of a carnival atmosphere which nobody could hide from.

The first stage of laughter simulation enabled man to play, feel the difference between elemental laughter, as an uncontrolled, spontaneous and direct response to the ridiculous and comicality, and feigned, imitated laughter and hence to fix in emotional memory and body memory their similarity and distinction. Imitation of laughter at that historical stage was an intuitive use of its qualities and functional capabilities for symbolic representation of existential realities and response to such specific circumstances as initiation, burial, carnival etc. as well as for ensuring communication, consolidation of community, social therapy, catharsis etc. In the course of time that ability to simulate laughter and a smile as its reduced form will be used in other than ritual actions.

A phenomenon of the American smile is an illustration of a new stage of laughter simulation. The American smile is peculiar misrepresentation of reality (J. Baudrillard) because due to its origin it involves disagreement between the internal emotional state and manifested facial expression. From the earliest times, a smile has been actively used in English and then also in American tradition of nonverbal communication for creation of an attractive public image. A smile makes an impression of success, builds up confidence, which raises the rating of a given person in the political and business world. Today a smile is an integral part of public self-presentation of American and British political leaders, business elite, celebrities and members of the royal family. Despite the fact that an overwhelming majority of people mostly perceive politicians' smiles as false courteous masks, smiles are still considered a certain social norm. The USA have a traditional smile fashion established, which helps the Americans overcome difficulties and stand up to hardships by pursuing their happiness and attaining their American dream. As representatives of structural linguistics assert, the expression keep smiling, which is common for American literature, is in itself indicative of a not exactly natural origin of a smile. The latter is here understood as an emotional sign-signal that can be put on or taken off the face on one's own accord.

In spite of an old American history of using positive emotionality, the phenomenon which we perceive as the American smile today has an absolutely definite origin time. The "American smile" took shape as a certain concept in American cognitive science at the turn of the $19^{\text {th }}-20^{\text {th }}$ centuries and its background features not only traditional behavior but also deep socio-philosophical and socio-psychological foundations. The period of prosperity (the 1920s) and Great Depression (1929-1933) should be considered as the time of theoretical justification and active introduction of the American smile into social practice. In the forefront of the developers of the American smile idea was the founding father of pragmatism, the most American philosophical system among all, William James. Contemporary expertscall him the leader who opened a new era for entire American philosophy. Owing to his efforts, the latter spurted into the lead and now gives a firm and unequivocal answer to its main question "What is the source of true knowledge?": "It is an action" [Мальцева, 2012: 35].

Following Herbert Spencer and Charles Peirce, James declares that only our feelings and our thoughts through which we influence an object of cognition as well as evaluation that we make on the basis of experience are undoubtedly real. Due to accessibility for observation and test by experience, practical actions now fall into place of mental elements. As a result, James's principle (that should be rightfully called "transformation of "Peirce's principle" in James's philosophy), under which the true is whatever turned out to be practically useful or beneficial, has become literally a symbol of American society. Subsequently it spread to the West as it is associated with philosophic expression of worldly views of the middle class. The above principle was also supported with enthusiasm by academic and business communities of the USA.

C. Peirce blessed it by declaring: "The truth lies in future utility for our purposes". J. Dewey confirmed it, fixing with a formula: "The verity is defined as usefulness" and clarified that it should be understood as consonance between an intention and a result (rather than between an idea and reality), "just as a key meets demands made by a lock". For wide business groups of the USA those excessively scientese statements had been by then unnecessary. In their language, James's principle meant that the truth could be tested in practice or rather tasted and that making profits from investments was evidence of their verity which was sanctified by heavens [Мальцева, 2012: 36]

Having transferred his principle from gnosiology to psychology, James created a new teaching of emotions which in the context of the above theory are a consequence rather than a cause of physiological changes. Independently of James, the same conclusion was arrived at by C. Lange at the turn of the $19^{\text {th }}-20^{\text {th }}$ centuries, however, the theory of emotions by James-Lange came with time under considerable criticism [Cannon, 1927: 106-112]. James believed that by behaving in a certain way, one might arouse respective emotions and therefore a simple and clear way would be opened up before man for adjustment of his/her psyche. As an experimental psychologist, James explored muscular and behavioral forms of manifestations of emotional states and found out that if, for example, good spirits were accompanied with a smile, you could improve your vitality by stretching the lips in a smile when you were in a bad temper [Cannon, 1927: 114-124]."Keep smiling!" and you will feel okey. The American slogan of the Great Depression times, "Keep smiling!", was called up by that very conception [Мальцева, 2012: 37].

James's theory of emotions together with I. Pavlov's teachings regarding acquired reflexes underpinned the development of behaviorism, a new school in psychology. According to behaviorism, the subject of the given science is behavior understood as a set of motor responses as well as reduced to them verbal and emotional responses (reactions) to impacts (stimuli) of the external environment rather than consciousness. The name "psychology without psyche" got stuck to behaviorism whereas the main result 
of research in that field became the statement that if man was subject to certain irritants, defined behavior could be a response.

In terms of social philosophy, it meant a prospect of optimizing future social relations. The theoretical leader of behaviorism John Watson who defined that school as a product of exclusively American science believed that behaviorism had to become a laboratory of society because it would lead America to general happiness. A smile was then assigned a special function: American society had to radiate success, satisfaction and joy, even in case of no objective causes for the above. The Americans with their smiling faces had to create a positive social background for future transformation of society and attract the American dream in their individual lives.

The American smile gradually turned into a commodity (stimulus) through which the Americans strove to draw respective dividends (reactions) in the form of job placement, promotion, rush of customers, sales of products, expansion of a set of adherents of certain political ideas or admirers of talent etc. As the adept of new pragmatic methods Dale Carnegie whose books are known all over the world pointed out: "Interpersonal skills are the same commodity bought for money as sugar or coffee" [Карне$2 u, 2006: 234-242]$. It is not without reason that in his popular book "How to Win Friends and Influence People" (1936) (which was fully based on ideas of W. James's and A. Watson's teachings) D. Carnegie places high emphasis exactly on the ability of maintaining one's own positive emotions and smiling. He insists that "(...) a genuine smile, filled with cordial good, coming from the bottom of the heart, (...) is appreciated at the exchange of human feelings" [Карнеги, 2006: 234-242]. And he proceeds with his advice by citing $W$. James: even if it is difficult for you now to smile sincerely, remember: "a conscious way to cheerfulness when it is lost is to collect yourself and force yourself to speak and behave so as if you have already achieved buoyancy (...), to smile" [Карнеги, 2006: 346352]. It should be noted that the ideology of the American smile has also had its impact on the development of mass culture and general moods of the postmodern period.

An important step toward simulation of laughter became an idea-phantasmagoria stated by the English writer Lewis Carroll in respect of a possibility of virtual existence of a smile without its referent. In his fairytale "Alice in Wonderland" (1865) the author creates a character of the Cheshire cat which is able to gradually dissolve into thin air, leaving only a grin as a memory. In that way there appeared an area of symbolic existence of laughter and a smile.

The technological expansion in the $20^{\text {th }}$-early $21^{\text {st }}$ centuries greatly expanded the potential for reproducing models of simulated laughter, there appeared its numerous visual, audio and virtual substitutes. That stage may be defined as "production" of simulated laughter, which was, firstly, underpinned by advanced technologies and, secondly, imbued with the spirit of profit and bourgeois craving for using laughter for commercial purposes. The spread of photo, TV and video advertising resulted in engaging laughter and smile images as an attractive commercial move. Hired models who advertised goods and services histrionically simulated those emotions, luring spectators as potential buyers by positive emotionality. That practice gave rise to the expression "laugh on/smile at the camera". Obviously, in case of posing we also deal with misrepresentation of reality and imitation of emotions.

Say, a series of smiling portraits of Marilyn Monroe, the diptych "Marilyn" and the painting "Four Marilyns" (1962) by the founder of commercial pop art Andy Warhol, lodged in the memory the image which became a symbol of the epoch, a sign and emblem of the postmodern. The portraits which were made from a popular photo of the actress are often compared with Mona Lisa by Leonardo Da Vinci (1503) by the way they influenced art. Warhol managed to skillfully fix the splitting, separation of the smile from its referent. Beyond that smile there is no more person, woman and actress left, there is a replicated sex symbol and there is a commercial sign only: the smile of Marilyn Monroe which stands apart from its bearer and lives its own life as the Cheshire cat grin.

Advertising needs no live emotions, it necessitates symbols which lure and sell. J. Baudrillard called rouged women's lips stretched in a smile and laughter on posters "simulacrum". He pointed out that rouged lips lost their natural purpose, they neither ate nor kissed, they were a mere name that lived on the work of imagination [Бодріяр, 2004b: 169-171]. "Painted lips do not talk: blissful, halfopen or half-pressed, they are unable to fulfil their common functions i.e. speaking, eating, puking or kissing. Instead of these ambivalent functions of exchange (...) there emerges an erotic cultural function of perversion, the lips irrepressibly lure as a conventional sign, a work of culture, as a game and rules of a game (...), rouged lips get objectified as a precious adornment, intensive erotic cost (...)" [Бодріяр, 2004b: 170].

Researchers of the current stage of laughter simulation are inclined to think that it is the use of so-called offscreen laughter which became the beginning of its commercial replication as well as an impetus to its objectification and dissolution in the scenery of daily routine.

Offscreen laughter was invented by Charles Douglas who introduced fake guffaw which quite habitually accompanies comic moments in television serials and various entertainment shows today. That idea crossed Douglas's mind for the first time as far back as in the early 1950 s when he was looking for some means to enhance or even replace a live reaction of television audience. Fake laughter had to be used to improve the ratings and expand the viewer ship. He solved that problem with the help of a special keyboard facility. Pressing the keys could produce different versions of laughter. Originally, offscreen laughter was used in episodes of the Jack Benny Show (1932-1965) and I love Lucie (1951-1957) whereas today its updated version has become common use [Мальцева, 2015: 1-4].

There are different interpretations of the offscreen laughter phenomenon. According to the publicist M. Kononenko, off screen laughter indicates a moment when something funny takes place on the screen for those who fail to catch the comic aspect themselves [Кононенко, 2005]. The philosopher A. Zupančič calls the effect of Douglas's invention "marking of a comic moment" [3yпанчич, 2004: 5-23]. The researcher V. Levchenko negatively estimates off screen laughter as, in his opinion, it is similar to explanation of an anecdote or joke, which kills the funny and prevents a viewer distinguishing it by himself/herself [Левченко, 2006: 137-142]. The contemporary philosopher of Slovenian origin Slavoj Žižek points out that there is (...) "that excessive presence which muffles and hides out of sightthe unheard paradox offscreen laughter. When we come to think of this phenomenon, we will see that it undermines our natural conception of our intimate emotions" [Жижек, 2004]. Žižek represents that phenomenon as insidious: after a short period of discomfort, when the TV screen literally laughs instead of you or in your place, you become gradually addicted. If you feel shortly shocked at the beginning as it is not easy to accept that some unknown facility laughs instead of you and it seems there is something unfailingly indecent in that phenomenon, in due course you get

\section{СХІД № 3 (155) травень-червень 2018 р.}


accustomed to the phenomenon and it is perceived as entirely natural. There is however something that keeps you worried even with the lapse of time: my intimate feeling may be radically externalized, I can weep and laugh through intermediary of somebody else [Жижек, 2004].

Strange as it is, but Douglas's invention proves that such primitive mechanism as offscreen laughter works in highly developed societies. Žižek writes that when he comes home in the evening too tired to set about something sensible, he may switch on the TV and simply watch a series of Smile, Friends or other serial; even if he doesn't laugh and just bluntly looks at the screen, having got tired after a difficult working day, he nevertheless feels more refreshed after that program. Žižek believes that offscreen laughter is not at all intended to make viewers laugh. On the contrary, the TV screen reacts to its jokes itself, allowing viewers to do something else and thus encouraging thoughtless, reckless activity. Saying that, it is important for authors of a show that viewers feel as if they laughed themselves [Жижек, 2004]. In fact, in this way there is a situation created when the subject of perception of the funny is eliminated and laughter is objectivized.

Robert Pfeifer has recently proposed a concept of interpassivity to describe a paradoxical phenomenon which appeared concurrent with new electronic media. In his opinion, there is no more any passive consumption of artistic works or texts - now I interact with the screen for the most part, entering in dialog relations rather than just look at it. However, there is also another side of interactive narratives: instead of passive observation of whatever is happening on the screen, they strip me of my own passive reaction of satisfaction (or mourning, or laughter). It turns out that the object itself enjoys the show instead of me. In other words, the subject of perception is withdrawn, the TV set lives its own life, it jokes by itself and responds to jokes itself. A viewer has become redundant. As the American writer and professional humorist Robert Orben jokes, it appears that Pavlov's conditioned reflex is real: whenever there is a canned laughter heard on the TV, the viewer in voluntarily yawns [Orben, 1986].

At the same time, there have been some attempts to find some positive qualities in this simulated laughter. Generally agreeing with Žižek, researchers of the other camp find some positive sides and significance in interpassivity of offscreen laughter, namely: an opportunity to keep the distance in respect of primitivism of mass culture and show business projects. A viewer can shift, so to say, the burden of consumer's pleasure on to someone else's shoulders, identify himself as a creative, thinking being with an adequate level of criticism and know the difference between the important, the significant, the real and artificial contrived simulations.

Very similar to offscreen laughter by technical parameters is the toy Laugh Bag" popular in the 1970-80s, which played recorded trills of laughter and started a laughing reaction of others owing to a contagion mechanism. Unlike offscreen laughter, laughter from the bag offers some suddenness and is not connected with anyone or anything, there is no even conditionally comic situation here. In this regard, laughter sounding from that device is an absolute simulacrum because it is nobody's anonymous laughter without any reason or by reason of nothing. That amusing toy is a telling illustration of the fundamental property of simulacra to act as principal inconsistency and incommensurability with any reality (G. Bataille). Despite being already an old joke, the toy Laugh Bag is in demand and even finds practical application when organizing children's games and pastimes, aimed at encouraging their positive moods and elation state.
The last stage of simulation, which is achieved through encoding when laughter as it is disappears, is the concluding one in the process of its simulacrization. Here we should distinguish such kinds of laughter simulacrization as objectivation, virtualization and formalization.

Specificity of the present day is the fact that most various objects and things radiate the funny and laughter is something which is imprinted and immanent in them. It seems that everything around us laughs at us and at the same time encourages us to laugh. This abstract code of laughter is embedded on the level of presentive materialization in speech in consequence of which it eventually breaks away from its referent. Emanations of laughter now come from outside rather than from an individual. Laughter loses the subject and dissolves into the object, getting objectified. Laughter becomes an autonomous signal which is simulated and as a simulacrum translates certain senses. As R. Barthes pointed out in "Empire of Signs" (1967), we faced a semiologic paradox when things and phenomena themselves began to claim rationality and ownership of senses [Барm, 2004].

Thus, postmodern architecture (functional ironism, kitsch) ridicules architectural styles of the previous epochs, identifying and immediately amending their gaps. Fashion promotes the creation of comic characters and calls for ironic, casual attitude to styling the appearance. Ironically are also perceived "(...) artificial flowers which are brighter and more beautiful than those natural, a marbled concrete wall, a combed plastic table, meat imitation soybean sausage and Music Factory singers who express the producer's concept and project rather than themselves, their state and feelings [Кремень, Ільїн, 2006: 315-316].

Another kind of simulation of laughter results from its virtualization when it should supposedly appear but there is none, i.e. there is a situation in place, which creates laughter, encourages it or makes it possible but leads to no psychophysical realization of laughter. Among such sociocultural practices which create conditions for virtualization of laughter one should mention various performances, flash mobs, happenings etc., where an indispensable condition for performers is prohibition of laughter. As a rule, they remark on those automatisms described by A. Bergson, which man assimilates, living in society, through following certain regulation, rule or algorithm and which are inadequate for a specific situation or event generating other senses. In tune with the above is also the theme of opposition of laughter to any stagnation, covered by G. Deleuze. "Laughter fights any stagnation and when stagnation takes shape, is embodied in flesh in a gesture, word or character, this body is a machine and machine stagnation always provokes laughter (...). By ruining mechanistic stagnation, laughter asserts neat movement, always extremely pronounced and theatrical. The movement signified by laughter is always a temper, a role of a character, depending on the scale of the movement itself [Маковецкий, 2004: 54].

Historical prerequisites of modern performance art are not only street performances and public merrymaking of buffoons but also acts of holy fools, which aimed primarily to change people's views and turn senses inside out rather than to entertain or make laugh. The above resulted in mixed feelings: surprise, laughter, shame, anger etc.

Another precondition of virtual (from Latin virtualis, meaning "possible) laughter i.e. the one which may or should arise, at least, in the mind's eye, is a flash mob.

Having originated in 2003 , today a flash mob phenomenon is explored from different scientific positions: as a phenomenon of arbitrary self-organization of open systems (L. lonina, M. Kogan); as a mass action arising on 
the boundary of common sense and performance in terms of a prank (this concept was legalized in social and philosophical discourse by V. Malakhov); as an element of the laugh world, which demonstrates a playing, ironic, theatrical and festive beginning of the postmodern (I. Golubovich). The first flash mobs were underpinned by Howard Rheingold's book "Smart Mobs: The Next Social Revolution" (2002) about unexpected communities. A flash mobis designed to delicately present a certain idea through cultural provocation, staging in a delicate way without pressing. Ideas manifested by flash mobs are expressed in a body-plastic form. As a rule, it is a speechless staging which conveys sense by the body language [Мальцева, 2011: 224-225].

Thus, a flash mob or a smart mob becomes a haven for simulated, latent laughter and convincing demonstration of a specific way of perceiving the postmodern, which is expressed by a point nature, discreteness and mosaicity. A flash mob makes understand that life is situational - each moment manifests itself here and now, is implemented (acquires content) and forgotten; the world of ideas is no static because of being pluralistic and fragmentary whereas sense fleetly appears and immediately disappears as a balloon in the sky. Staging actions of a flash mob allow to observe how senses are born in chaos but to border senses which slip out and mark the lines of the possible rather than to determine them" [Мальцева, 2011: 224-225]

As $\mathrm{V}$. Okorokov points out, interpreting the schizoanalysis by Deleuze and Guattari, "(...) chaos is far from being emptiness, it is rather a flow of events which quickly vanish from today's horizon (changes in process are so significant that an external observer has no time to respond; extrinsically, there is a complete lack of senses exposed). According to Deleuze, an event is rigidly connected to formation which main feature is escape from the present" [Окороков, 2006: 75] "Space of senses is an ascending surface area of the rhizome thought-world whereas a letter, language or laughter are different alternatives of surface revelation of its senses" [Окороков, 2006: 78]. Simulation of laughter in this case is a form of fixing the states, unfixable in principle, which open a horizon of an event when there is deadly and tough certainty on one side and implosion of sense, an insight, on the other one.

Another variety of laugher simulation is formalization of emotions as a means of informal communication in virtual space. As is known, man continually experiences whatever happens to him/her and whatever he/she does. This experience of social realm creates a rich and bright sphere of human feelings, emotional states and reactions which in the course of interpersonal interaction are directly perceived by others as important signals about the significance for an individual of certain events, phenomena, processes in the context of his/her needs and interests. Contemporary communication technologies however greatly reduce direct contacts between people. Communication in virtual space through websites, email and sms has become everyday practice and is no more limited to business exchange of information. Users of electronic communication means try to impart all features of full value to a new type of written correspondence, including a capability to show emotional nuances of a thought or changes which take place in their emotional sphere during the given contact.

To make up for impossible reading of the whole variety and dynamics of feelings of virtual vis-a-vis as well as to convey one's own emotions, there were special symbols put into practice, which were generally named "smileys" (from English smile; ;) or :), the first emoticon), as well as numerous acronyms and Internet memes. Essentially, emotions have been formalized, i.e. a semiotic (sign) system has been created. It is a peculiar symbolic language of emotions, which allows to convey exhilaration, delight, admiration, ecstasy, anger, rage, fear, joy, irritation, tears, laughter, fright, surprise, fury, rampage, grief etc. [Мальцева, 2010: 255].

As any language of symbols, smileys (emoticons) have all necessary attributes of a sign system, namely:

- precision - they eliminate polysemy of a natural language, which rules out a possibility of their varying interpretation as a result;

- visualization - these sings-symbols fulfil the task of stenography, shorten the writing (or rather the description of a great range of emotional states) and allow to manually manipulate them;

- structural properties - capability to fit well into a text i.e. to find a clear expression in the structure of a natural language [Мальцева, 2010: 255].

Virtual space also makes a frequent use of acronyms and Internet memes for conveying the emotional state dynamics. Thus, the acronym LOL [McKean, 2005] has relatively recently gained currency (it is also used as lol; from English laughing out loud; or laugh out loud; lots of laughs). It is an English acronym used in the written form in network communications. In March 2011, LOL as well as other symbols and acronyms were entered in the Oxford Dictionary. In addition, there are numerous memes and acronyms in place for defining shades of laughter, ranging from a forbearing smile to cutting irony and sarcasm [Franzini, 2002].

Nevertheless, despite all the positivity of attempts to somehow enliven and humanize virtual space, make it informal by introducing a language of feelings, formalization of emotions fails to exhaust all the wealth of nuances of human emotional experience and sensitivity as well as intimacy and warmth of direct communication; it can only sequentially verge towards this goal, always remaining their ersatz. At the same time, today laughter having had various semantics at all times, which was told a good deal about in works by G. Bataille, J. Derrida, K. Lévi-Strauss, L. Lévy-Bruhl, O. Freidenberg, M. Bakhtin, L. Karasiov, D. Likhachov et al., has been acquiring other symbolic expressions, demonstrating its unlimited potentialas to emergence of yet new modi.

\section{Conclusions}

Historically, simulation of laughter took place according to the algorithm proposed by J. Baudrillard (imitation production - simulation). In the final stage simulated laughter presents itself as a range of various kinds: visual and psychophysiological simulation (advertising laughter and smiles, the American smile), mechanical audio playback of laughter (the Laugh Bag, off screen laughter), formalization of emotions (emoticons, smileys, acronyms, Internet memes such as (:) and lol), virtualization of laughter through its non-voiced appearance as sense certainty of the ridiculous in situational actions, performances, flash mobs; objectivation of laughter in welfare items, architecture, fashion stylistics in respect of the appearance, interiors etc.).

With time, simulated laughter has been replacing communication with simulation of intercourse. It finds itself beyond the true and the erroneous, beyond rational differences which underpin the functioning of the social. The above leads to hyper reality where simulated laughter is more real than the natural one, which results in further abolition of the latter. Simulacrization of laughter as a historical process demonstrates that sociocultural space continually features different historical types of laughter

\section{СХІД № 3 (155) травень-червень 2018 р.}


but each of them has a certain acme period of the highest development, the completeness of its form. Postmodern landscapes and the development of IT technologies revealed in the best way simulated quality of laughter, its fluidity, plasticity, variability, ability to overcome boundaries and limits, to change, be insincere, false, feigned, ostentatious, sly, insidious, phantom, shadowy and imaginary. Laughter transgresses constantly between reality and hyperreality, between the world of live emotions and the symbolic world of signs, between the spheres of corporeity and ratio, between hierarchized systems of senses, dead structures of meanings and nothing etc. It presents itself to us as importunate strange guffaw and instantaneous flash of silent laughter.

Thus, it may be concluded that even simulated laughter performs multiple-vector social functions: on the one hand, it reduces to an absurdity the state of hyperreality, on the other hand, as a set-off to the latter, it allows to wake up from its hypnosis and focus on topical values and live emptions as well as to conceive the unconceived.

\section{REFERENCES}

1. Bart, R. 2004. Empire of signs [translat.]. Praxis, Moscow: 144 p. (rus).

2. Baudrillard, Jean 2004a. Simulacra and Simulation [translat.]. Osnovy, Kyiv, 230 p. (ukr).

3. Baudrillard, Jean 2004b. Symbolic exchange and death [translat.]. Calvaria, Lviv, 376 pp. (ukr).

4. Cannon, Waiter (December 1927). The James-Lange Theory of Emotions: A Critical Examination and an Alternative Theory. The American Journal of Psychology. No. 39: 106-124. DOI: 10.2307/ 1415404

5. Carnegie, D. 2006. How to Win Friends and Influence People [translat.]. Martin Publ., Moscow, 400 p. (rus).

6. Franzini, R. Louis. 2002. Kids Who Laugh: How to Develop Your Child's Sense of Humor. Square One Publishers, Inc, 2002. 153 pp. (eng).

7. Klossowski, P. 1994. Simuliakr Georges Bataille [translat.]. In: Thanatology of Eros. Mithral Publishing, St. Petersburg: 82 (rus).

8. Kononenko, M.V. 2005. The command «ridiculous» Ogonyok: journal. № 28 (4907) for July 11-16 (rus).

9. Kremin, V.G. and llyin, V.V. 2006. Simulakr. Philosophy: Logos, Sofia, Reason. Knyha Publishing, Kyiv, 432 p. (ukr)
10. Levchenko, V. 2006. Laughter as a distinction. Doksa. Collection of scientific works on philosophy and philology. Odessa National University. Issue. 9: 137-142 (ukr).

11. Makovetskiy, E.A. 2004. Social analytics of rhythm. Gilles Deleuze or of salvation. Publishing House of St. Petersburg University, St. Petersburg (rus).

12. Maltseva, O. V. 2010. Formalization of emotions as a means of informal communication in a virtual space. University science2011: International scientific - technical. Conf., Priazovsky State Technical University, Mariupol, May 18-20, 2010 Mariupol: GSTU «PSTU», 2010. Vol. III: 255 (ukr)

13. Maltseva, O. V. 2011. Flash mob as a situational and provocative manifestation of postmodern worldview. University science-2011: International scientific - technical. Conf., Priazovsky State Technical University, Mariupol, May 17-19, 2011 Mariupol: GSTU «PSTU», 2011. Vol. III: 224-225 (ukr)

14. Maltseva, O. V. 2012. «Keep smiling!»: philosophical and socio-psychological foundations of the "American smile» The Newest Achievements of European Science-2012: VII I International Scientific Practical Conference, Sofia, 17-25 July 2012.Sofia: «WhiteGRAD-BG» Ltd, Vol.8: 35-37 (ukr).

15. Maltseva, O. V. 2015. Reproduction of simulation models and their meanings: Footage laughter. Modern scientific trends: III (LV) International scientific-practical conference on philosophical, philological, legal, pedagogical, economic, psychological, sociological and political sciences, Kyiv, March 27, Pantyukh Yu.F. Publisher, Kyiv: 1-4 (ukr).

16. McKean, Erin. 2005. The New Oxford American Dictionary. 2. - adds 'LOL', 'BFF'; other slang. Square One Publishers, Inc, 2051 pp. (eng).

17. Okorokov, V.B. 2006. Face and folds of the society (Transgression of laughter) Doksa. Collection of scientific works on philosophy and philology. Odessa National University. Issue. 9: 71-78 (ukr).

18. Orben, R. 1986. 2100 Laughs for All Occasions. Main Street Books, 240 pp. (eng).

19. Plessner, Helmut. 2003. Laugh and cry. An Examination of the Limits of Human Behavior 1941. Expression and Human Nature. Collected Works VII. Frankfurt am Main: 201-387 (germ).

20. Zupančič, A. 2004. Eros and Comedy, or Subject and Surplus Pleasure [translat.]. Gender Studies. No. 11: 5-23 (rus).

21. Žižek, S. 2004. Giggle me please. Slavoj Žižek about passive perception and laugh track. Available at: http:// www.vavilon.ru/textonly/issue12/zhizhek.htm

Мальцева Ольга,

кандидат філософських наук, дочент,

Приазовський державний технічний університет, м. Маріуполь

\section{СИМУЛЯКРИЗАЦІЯ СМІХУ: ДОСВІД РЕКОНСТРУКЦІї}

У статті досліджується феномен постмодерної симулякризації сміху на тлі постійного перетворення реальності на гіперреальність та новим функціональним впливом відомих симулякрів на індивіда і суспільство. На підставі запропонованого Ж. Бодрійяром універсального алгоритму симулякризації ("підробка - виробництво - симуляція") проведено історичну реконструкцію процесу симулякризації сміху та продемонстровано, що у соціокультурному просторі постійно представлені різні історичні типи сміху, але у кожного 3 них є певний період "акме" найвищого розвитку, завершеності форми. Визначено, що у завершальній фазі симулякризований сміх постає у низці різновидів: візуальна та психофізіологічна симуляція (рекламний сміх і посмішки, "американська посмішка"), механічне аудіо-відтворювання сміху ("мішечок сміху", закадровий сміх), формалізація емоції (емотікони, смайли, акроніми, Інтернет-меми на кшталт : i "lol/лол"), віртуалізація сміху через його не вокалізоване явлення як смислової "вірогідності смішного" у ситуативних діях, перформансах, флешмобах; об'єктивація сміху у предметах побуту, архітектурі, модній стилістиці щодо оформлення зовнішності, інтер'єрів тощо).

Автор доводить, що саме симулякризований сміх сприяє підміні справжньої комунікації симуляцією спілкування і формуванню світу гіперреальності, який наповнюють символи знаків та конструкції значень, та виконує різновекторні соціальні функції: з одного боку, доводить до абсурду стан гіперреальності, а 3 іншого, - на контрасті із нею дозволяє прокинутися від їі гіпнозу та зосередитися на актуальних цінностях і живих емоціях, збагнути незбагненне.

Ключові слова: сміх; постмодерна симулякризація сміху; соціальні фуункції сміху. 
1. Барт Р. Империя знаков. Москва: Праксис, 2004. 144 с.

2. Бодріяр Ж. Симулякри і симуляція. Київ: Основи, 2004. 230 с.

3. Бодріяр Ж. Символічний обмін і смерть. Львів: Кальварія, 2004. 376 с.

4. Cannon, Waiter. The James-Lange Theory of Emotions: A Critical Examination and an Alternative Theory. The American Journal of Psychology. № 39 (December 1927). P. 106-124.

5. Карнеги Д. Как приобретать друзей и оказывать влияние на людей. Москва: Мартин, 2006. 400 с.

6. Franzini R. Louis. Kids Who Laugh: How to Develop Your Child's Sense of Humor. Square One Publishers, Inc, 2002.153 p.

7. Клоссовски П. Симулякры Жоржа Батая. В: Танатология Эроса. СПб.: Мифрил, 1994. С. 82.

8. Кононенко М. В. Команда «смешно». Огонёк: журнал. 2005. № 28 (4907) за 11-16 июля.

9. Кремень В. Г., Ільїн В.В. Симулякр. Філософрія: Логос, Софрія, Розум. Київ: Книга, 2006. 432 с.

10. Левченко В. Смех как различение. Докса. Збірник наукових праць з філософрії та фрілології. Одесса: Одеський національний університет ім. І. І. Мечникова, 2006. Вип. 9. С. 137-142.

11. Маковецкий Е.А. Социальная аналитика ритма. Жиль Делез или о спасении. СПб.: Изд-во С-Петербургского ун-та, 2004.

12. Мальцева О. В. Формалізація емоцій як засіб неформальної комунікації у віртуальному просторі. Университетская наука - 2010: Международная научно-техн. конф., Приазовский государственный технический университет, г. Мариуполь, 1820 мая 2010 г. Мариуполь: ПГТУ, 2010. Т. III. С. 255.

13. Мальцева О. В. Флеш-моб як ситуативно-провокативна маніфестація постсучасного світосприйняття. Университетская наука - 2011: Международная научно - техн. конф., Приазовский государственный технический университет, г. Мариуполь, 17-19 мая 2011 г. Мариуполь: ГВУЗ «ПГТУ», 2011. Т. III. С. 224-225.

14. Мальцева О. В. «Кеep smiling!»: філософські та соціально-психологічні підвалини «американської посмішки». Найновите постижения на европейската наука-2012: VII I Международна научна практична конфреренция, София, 17-25 юли 2012. София: «Бял ГРАД-БГ» ООД, 2012. Т. 8. С. 35-37.

15. Мальцева О. В. Репродукування моделей симуляції та їх смисли: закадровий сміх. Современные научные тренды: III (LV) Международная научно-практическая конференция по философрским, фрилологическим, юридическим, педагогическим, экономическим, психологическим, социологическим и политическим наукам, г. Киев, 27 марта 2015 г. - Киев: ФЛП Пантюх Ю.Ф., 2015. C. 1-4.

16. McKean Erin. The new Oxford American Dictionary. 2 adds 'LOL',"BFF; other slangю. Square One Publishers, Inc, 2005.2051 p.

17. Окороков В. Б. Лик и складки социума (Трансгрессии смеха). Докса : Збірник наукових праць з філософії та фрілології. Вип. 9. Семантичні й герменевтичні виміри сміху. Одеса, 2006. С. 71-78.

18. Orben R. 2100 Laughs for All Occasions. Main Street Books, 1986. 240 p.

19. Plessner Helmut. Lachen und Weinen. Eine Untersuchung der Grenzen menschlichen Verhaltens 1941. Ausdruck und menschlichen Natur. Gesammelte Werke VII. Frankfurt am Main, 2003. S. 201-387.

20. Зупанчич А. Эрос и комедия, или Субъект и прибавочное удовольствие. Гендерные исследования. 2004. № 11. С. 5-23.

21. Жижек C. Похихикай мне, пожалуйста. Славой Жижек о пассивном восприятии и закадровом cмexe. URL: http:// www.vavilon.ru/textonly/issue12/zhizhek.html

(C) Maltseva Olga

Надійшла до редакції 29.04.2018 